\title{
Managing the Yield and Quality of Grapes by Calcium Supplementing on Foliar Way
}

\author{
Florin SALA $^{1^{*}}$, Alin DOBREI ${ }^{2}$ \\ ${ }^{1}$ Soil Science and Plant Nutrition, Banat University of Agricultural Sciences and Veterinary Medicine \\ "Regele Mihai I al României" from Timisoara, Calea Aradului 119, Romania \\ ${ }^{2}$ Horticulture, Banat University of Agricultural Sciences and Veterinary Medicine "Regele Mihai I al \\ României" from Timisoara, Calea Aradului 119, Romania \\ *)corresponding author, e-mail: florin_sala@usab-tm.ro
}

BulletinUASVM Horticulture 72(2) / 2015

Print ISSN 1843-5254, Electronic ISSN 1843-5394

DOI:10.15835/buasvmcn-hort:11362

\begin{abstract}
Taking into account the ecobiology and the features of nutrition in grapevine, monitoring nutrition is a process with a very dynamic balance. Present research assessed the way in which supplementary foliar fertilization with calcium can have a positive impact on grape yield, both quantitatively and qualitatively. Were used three foliar fertilizers - Fertitel, Cropmax and Waterfert - alone or associated with calcium. As indicators of the nutrition state, were analyzed the leaf area and chlorophyll content and as yield elements were evaluated mean yield per vine, mean yield per ha, and dry matter content in grapes upon harvesting. The biological material consisted of the "Burgund" grapevine cultivar. According to the Anova statistical analysis, trial results point to high statistic ensurance $\left(\mathrm{p}<<0.001, \mathrm{~F}_{\text {calculated }}>\mathrm{F}_{\text {theoretical }}\right.$ for Alfa $=$ 0.001). The variation of leaf area was strongly influenced by climatic factors compared with chlorophyll content variation which was heavily dependent on fertilizer. Yield per vine and yield per ha have recorded variations depending on climatic condition and fertilizer, but were more stable with calcium supplement. Based on the PCA analysis, trial data were arranged into two groups $\left(\mathrm{G}_{1}\right.$ with the variants $\mathrm{V}_{2}, \mathrm{~V}_{4}$ and $\mathrm{V}_{6}$, and $\mathrm{G}_{2}$ with the variants $\mathrm{V}_{3}, \mathrm{~V}_{5}$ and $\left.\mathrm{V}_{7}\right)$. The main factor generating variation between the two groups was the supplementary treatment with calcium associated to the group $\mathrm{G}_{2}$. Grouping trial variants based on Euclidean distances were highly safe, the value of the cophenetic coefficient being 0.940 .
\end{abstract}

Keywords: calcium, foliar fertilization, grapevine, quality, vegetation indices, yield.

\section{INTRODUCTION}

The importance of soil and also of field exposure and microclimate within the concept of terroir (Van Leeuwen and Seguin, 2006) is well known in the definition of wines. The concept of terroir is associated with quality and excellence of grape and wine products (Van Leeuwen et al., 2004; Mouton, 2006; Charters, 2010; Rotaru et al., 2010; Cross et al., 2011; Teil, 2012). Soil as a complex heterogeneous medium does not always have the necessary grapevine nutrients though the soil volume explored by its root system is very wide (Bassoi et al., 2003; Bauerle et al., 2008). A series of factors such as morpho-physiological, physical, chemical, and micro-biological - that have been largely studied (Barbeau et al., 2001;
Mackenzie and Christy 2005; Andrés-de-Prado et al., 2007; Lambert et al., 2008; Smith et al., 2008; Freitas et al., 2011; Felder et al., 2012; Olivier et al., 2013) affect water and soil nutrients regime in relation to grapevine.

Grapevine has high requirements from the nutrient regime, if it is taking into account the differentiated distribution of the water and nutrients, on grape yield and biomass growth (IFA 1992). Sometimes, unbalanced physico-chemical composition or soil moisture deficit (on the background of unfavorable climatic conditions), the grapevine-soil relationship can be unbalanced, and this needs correction measures. Numerous studies and researches have monitored the grapevine-soil relationship and the opportunity 
to correct the vine nutrition status through fertilization (Neilsen et al. 1989; Jackson and Lombard 1993; Spayd et al. 1994; Wade et al. 2004; Colapietra and Alexander 2006; Sala and Blidariu, 2012; Sala et al., 2013; Blidariu et al., 2013).

The effect of fertilizers applied to the soil is sometimes reduced due to of unfavorable conditions. Thus, external factors (such as rainfall regime) with direct impact on soil features as a nutrition medium, influence the nutrient regime in grapevine nutrition, which can jeopardizing yields and quality. Foliar fertilization is an option, that is made more frequently, because of the higher efficacy of nutrients applied on the leaves, where they are absorbed and used in metabolic processes (Wiens and Reynolds 2008; Brataševec et al., 2013). On medium to goof fertility soils (that ensure an optimum level of the main macroelements $-\mathrm{N}, \mathrm{P}, \mathrm{K}$ ), foliar fertilization is the way of supplementing the other nutrients important in grape quality and grape and wine products. Supplementing secondary macro-elements (particularly $\mathrm{Ca}$ and $\mathrm{Mg}$ ) and microelements, or applying other bioactive substances on the leaves is very effective. Numerous researches have monitored this aspect under different soil and climate conditions (Gerasopoulos et al., 1996; Basiouny and Basiouny, 2000; Gluhić et al., 2009; Koutinas et al., 2010; Šimanský and Ložek 2013).

From this perspective, present research assessed the way in which calcium supplement through foliar fertilization can have an impact on vine yield, both quantitatively and qualitatively.

\section{MATERIALS AND METHODS}

This study had main purpose at assessing the influence of additional fertilization with calcium, through foliar way, on production and quality at vines. Research was carried out in Fruit-Vine Research Center at the Didactic Experimental Station of the Banat's University of Agricultural Science and Veterinary Medicine of Timișoara, Romania. The experiment field was located in the plot LL 474, at coordinates $45^{\circ} 78^{\prime} 89^{\prime \prime} \mathrm{N}$ and $21^{\circ} 21^{\prime} 66^{\prime \prime}$ E during 2011-2012 growing seasons.

The soil in the vine experimental plot was characterized by a neutral $\mathrm{pH}$ in the horizon $0-20 \mathrm{~cm}(\mathrm{pH}=6.85)$ and slightly acidic in the horizon $20-40 \mathrm{~cm} \mathrm{(pH}=6.47)$. Humus content $(\mathrm{H})$ amounted to $1.86 \%$ in the $0-20 \mathrm{~cm}$ horizon and $1.75 \%$ in the $20-40 \mathrm{~cm}$ horizon. Total nitrogen content (Nt) vas $1.14 \%$ and $1.11 \%$, respectively. Available phosphorus content was 31.74 ppm in the horizon $0-20 \mathrm{~cm}$ and $25.15 \mathrm{ppm}$ in the horizon 20-40 cm. Available potassium (K) content was $168.27 \mathrm{ppm}$ in the $0-20 \mathrm{~cm}$ horizon and $155.63 \mathrm{ppm}$ in the $20-40 \mathrm{~cm}$ horizon. General climatic conditions, specific to the trial area, are typical to the temperate continental climate with Mediterranean influences. During the trial period, mean daily temperatures were higher compared to the multi-annual means especially between May and September (Fig. 1).

As for the precipitations, there were two periods of rainfall deficit compared to the multiannual mean: the first interval of rainfall deficit was in May-June and first decade of July and the second interval of rainfall deficit was in the third decade of July and in August-September (Fig. 2).

The biological material was represented by "Burgund" grapevine cultivar. Management of grapevine nutrition was achieved through foliar fertilization with Fertitel, Cropmax and Waterfert applied alone ( $0.5 \%$ concentration) and associated

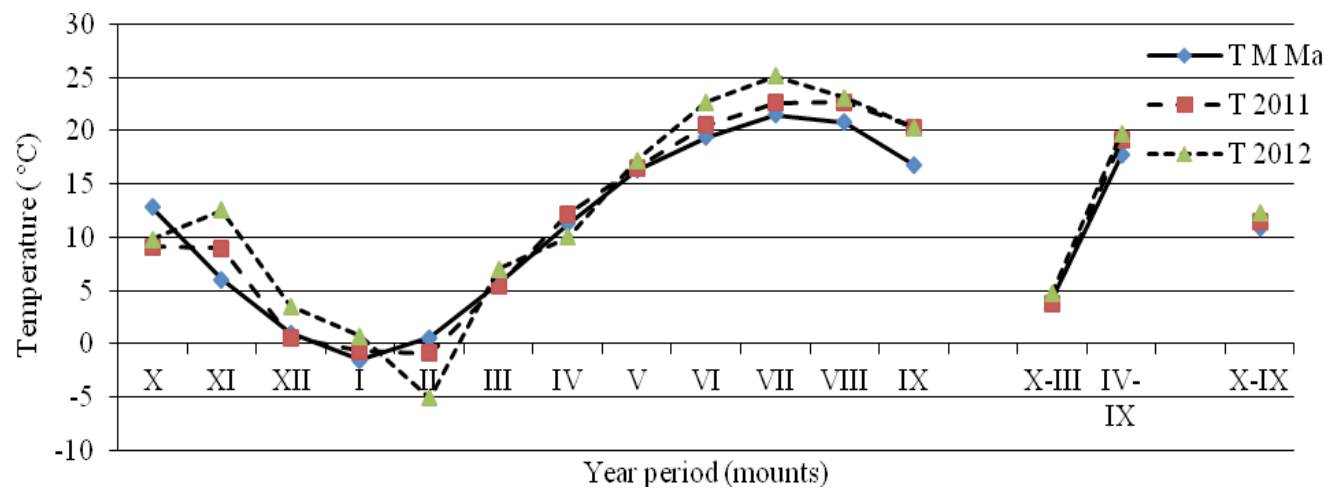

Fig. 1. Mean temperature during the trial period; T M Ma - multiannual mean temperature; $\mathrm{T} 2011$ - the temperature in 2011; T 2012 - the temperature in 2012. 
with CalcioPlus $(0.5 \%)$. Along with control variant given by the soil natural fertility $\left(\mathrm{V}_{1}\right)$, the combination of the fertilizers generated six trial variants: $V_{2}$ - Fertitel, $V_{3}$ - Fertitel + CalcioPlus, $V_{4}$ Cropmax, $\mathrm{V}_{5}$ - Cropmax + CalcioPlus, $\mathrm{V}_{6}$ - Waterfert, $\mathrm{V}_{7}$ - Waterfert + CalcioPlus. Experimental variants were set at random with three repetitions. Foliar fertilizers were applied in three treatments, at an interval of 15 days, first treatment before blooming.

The experimental data of nutrition status (leaf area by nondestructive method based on leaf dimension; chlorophyll content by nondestructive method with portable chlorophyll meter SPAD-502 Plus, Konica Minolta), vine production and quality (sugar content by refractometry), were processed through analysis of variance (ANOVA) using the mathematical module on EXCEL 2007. Descriptive statistics, correlations coefficient $\left(\mathrm{R}^{2}\right)$, regressions analysis, multivariate and PCA analysis were made using the PAST software (Hammer et al., 2001). The symbol ${ }^{*},{ }^{* *}$ and ${ }^{* * *}$ used in the paper represent statistically significance at $99.9 \%\left(\mathrm{LSD}_{0.01 \%}\right), 99 \%$ $\left(\mathrm{LSD}_{0.1 \%}\right)$ and $95 \%\left(\mathrm{LSD}_{0.5 \%}\right)$ probability level.

\section{RESULTS AND DISCUSSIONS}

The influence of foliar fertilization on the "Burgund" grapevine cultivar was assessed through the prism of some vegetation indices such as leaf area and chlorophyll content. Trial values in the two parameters point out the differentiated response of the grapevine to the grapevine assortment and combination of fertilizers. Were also noted a variation of the nutrition parameters depending on the vegetation conditions during the trial period, particularly depending on the uneven distribution of the rainfalls (Tab. 1).
Vegetation parameters (leaf area and chlorophyll content) were determined ten days after the third treatment, at opposite leaf bunch (20 leaves for each variant). Leaf area is an eloquent indicator of the vegetation and nutrition state in grapevine: it oscillated within both trial variants and trial periods. Leaf area measured, in 2011, between $102.27 \pm 1.86 \mathrm{~cm}^{2}$ in control variant $\left(\mathrm{V}_{1}\right)$ and $134.90 \pm 2.62 \mathrm{~cm}^{2}$ in the variant $\mathrm{V}_{3}$ (Fertitel + Calcio plus). In 2012, on the background of rainfall deficits, the values of this parameter were lower, but differentiated between trial variants. In the control variant $\left(\mathrm{V}_{1}\right)$, the leaf area was $97.65 \pm 1.69$ $\mathrm{cm}^{2}$ while the largest leaf area $\left(125.27 \pm 1.65 \mathrm{~cm}^{2}\right)$ was in the variant $\mathrm{V}_{3}$.

Chlorophyll content also varied depending on the fertilizers applied, between $30.02 \pm 0.65$ and $37.67 \pm 0.74$ SPAD units in 2011 , with a wider variation span than in 2012, when it oscillated between $30.68 \pm 0.67$ and $34.59 \pm 0.69$ SPAD units. Through the prism of the two parameters analyzed, foliar fertilizers were valorized more effectively in 2011, when climate conditions were more favorable from the point of view of the rainfall regime and of the soil hydric level. The comparative analysis of trial results concerning the nutrition state in grapevine pointed out a positive correlation between the two parameters - leaf area and chlorophyll content. The interrelation level between the two parameters as an expression of the grapevine nutrition state as correlation coefficient was $\mathrm{R}^{2}=0.968(\mathrm{p}<0.01)$ in 2011 and $R^{2}=0.949(p<0.01)$ in 2012, as shown in Figure 3 below.

The values of leaf area and chlorophyll content could be found in the yield and quality elements of the "Burgund" grapevine cultivar.

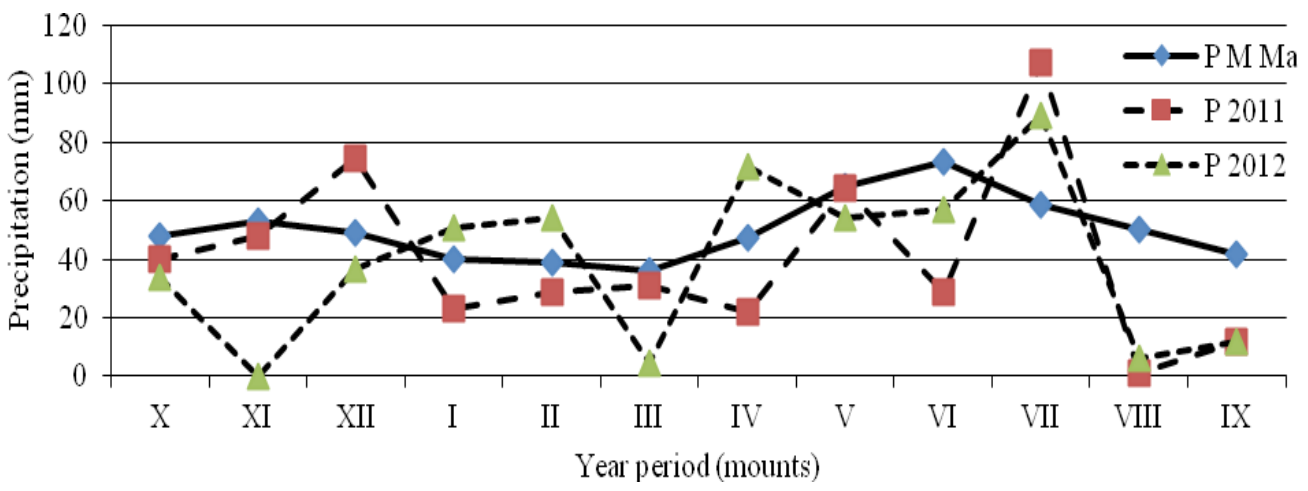

Fig. 2. Rainfalls distribution during the trial period; PM Ma - multiannual mean rainfall; P 2011 - rainfall in 2011; P2012 - rainfall in 2012. 
Differentiated state of nutrition in the grapevine by foliar fertilization and expressed as vegetation parameters, has influenced grapevine yield both quantitatively and qualitatively. The influence level was assessed through mean productivity per vine, mean yield per ha, and sugar content in grapes as a quality element (Tab. 2).

Mean values of productivity in 2011 ranged between $1.94 \mathrm{~kg} /$ vine in the control variant $\left(\mathrm{V}_{1}\right)$ and $2.97^{* * *} \mathrm{~kg} /$ vine in the variant $\mathrm{V}_{3}$ (Fertitel + Ca). In 2012, the less favorable vegetation conditions (because of the rainfall deficit) caused lower valorization of foliar fertilization. Mean productivity per trial variants ranged between $1.75 \mathrm{~kg} /$ vine in the control variant $\left(\mathrm{V}_{1}\right)$ and $2.35^{* *}$ $\mathrm{kg} / \mathrm{vine}$ in the variant fertilized with Fertitel in association with calcium $\left(\mathrm{V}_{3}\right)$. The values of mean productivity in the trial variants reflected in the grape yield per area unit, which ranged between 8.46 t ha $^{-1}$ in the control variant $\left(\mathrm{V}_{1}\right)$ and $12.50^{* * *}$ t ha ${ }^{-1}$ in the variant $V_{3}$ in 2011, and between 8.11 and $10.42^{* * *} \mathrm{t} \mathrm{ha}^{-1}$ in the same trial variants as in 2012, respectively (Tab. 2). According to the ANOVA statistic analysis, trial results are highly statistically ensured $\mathrm{p}<<0.01, \mathrm{~F}_{\text {calculated }}>>\mathrm{F}_{\text {theoretical }}$ for Alfa $=0.001$ (Tab. 3).

They were identified interdependence relationships between mean productivity per vine and mean yield per area unit, which facilitated the establishment of some mathematical function for the prediction of yield per ha based on mean productivity per vine, highly statistically ensured: $\mathrm{p}<0.01 ; \mathrm{R}^{2}=0.955$ for 2011 equation (1), and $\mathrm{p}<$ $0.01 ; R^{2}=0.970$ for 2012, equation (2) (Fig. 4).

Tab. 1. Vegetation indices in the "Burgund" grapevine cultivar

\begin{tabular}{cccccc}
\hline \multirow{2}{*}{ Variant } & $\begin{array}{c}\text { Trial } \\
\text { variant }\end{array}$ & $\begin{array}{c}\text { Leaf area } \\
\left(\mathrm{cm}^{2}\right)\end{array}$ & $\begin{array}{c}\text { Chlorophyll } \\
\text { (SPAD units) }\end{array}$ & $\begin{array}{c}\text { Leaf area } \\
\left(\mathrm{cm}^{2}\right)\end{array}$ & $\begin{array}{c}\text { Chlorophyll } \\
\text { (SPAD units })\end{array}$ \\
\cline { 3 - 6 } & & \multicolumn{2}{c}{2011} & & 2012 \\
\hline Control & $\mathrm{V}_{1}$ & $102.27 \pm 1.86$ & $30.02 \pm 0.65$ & $97.65 \pm 1.69$ & $30.68 \pm 0.67$ \\
\hline Fertitel & $\mathrm{V}_{2}$ & $129.30 \pm 2.12$ & $37.40 \pm 0.23$ & $124.77 \pm 2.65$ & $33.98 \pm 0.39$ \\
\hline Fertitel $+\mathrm{Ca}$ & $\mathrm{V}_{3}$ & $134.90 \pm 2.62$ & $37.67 \pm 0.74$ & $125.27 \pm 1.65$ & $34.59 \pm 0.69$ \\
\hline Cropmax & $\mathrm{V}_{4}$ & $122.47 \pm 2.81$ & $33.44 \pm 0.41$ & $116.70 \pm 2.04$ & $32.10 \pm 1.11$ \\
\hline Cropmax $+\mathrm{Ca}$ & $\mathrm{V}_{5}$ & $125.43 \pm 1.45$ & $35.18 \pm 0.72$ & $121.67 \pm 2.33$ & $33.59 \pm 0.77$ \\
\hline Waterfert & $\mathrm{V}_{6}$ & $123.47 \pm 2.11$ & $33.78 \pm 0.88$ & $117.47 \pm 1.78$ & $32.68 \pm 0.26$ \\
\hline Waterfert $+\mathrm{Ca}$ & $\mathrm{V}_{7}$ & $127.13 \pm 3.04$ & $34.90 \pm 0.15$ & $120.40 \pm 3.48$ & $33.75 \pm 0.27$ \\
\hline
\end{tabular}

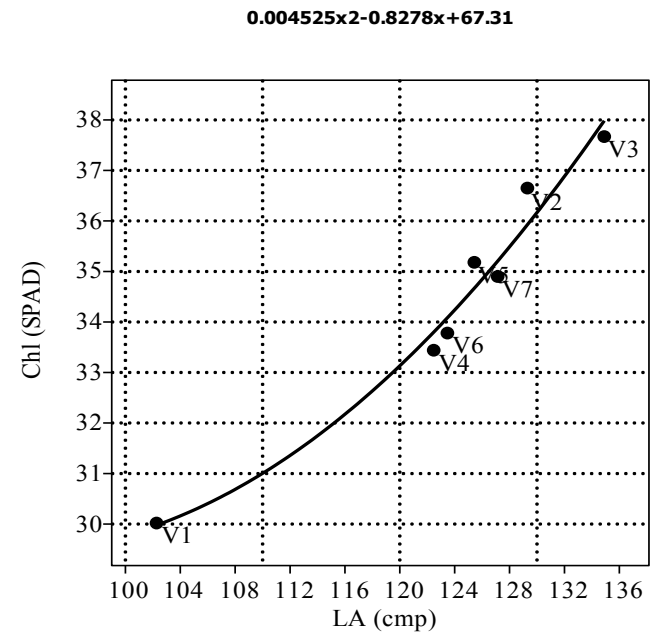

a

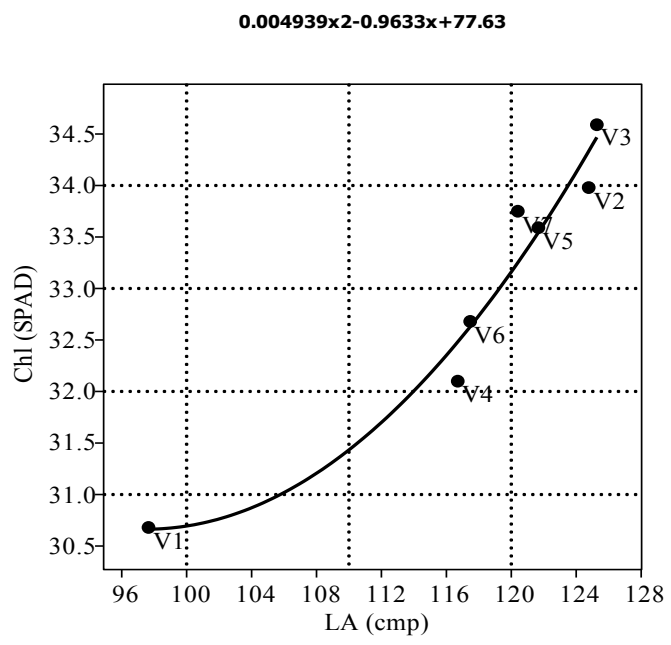

$\mathrm{b}$

Fig. 3. Interdependence relationship between foliar area and chlorophyll content in the 'Burgund' grapevine cultivar under the influence of foliar fertilization in 2011 (a) and 2012 (b); LA - leaf area; Chl - 


$$
y_{2011}=2.578 x^{2}-9.054 x+16.55
$$

$$
y_{2012}=-0.0344 x^{2}+4.426 x+0.2328
$$

\section{Where:}

$\mathrm{y}_{2011}$ and $\mathrm{y}_{2012}$ are the mean yields per ha during the trial period;

$x$ is the mean yield per vine;

$a, b, c$ are the coefficients of the trial conditions.

The analysis of the variation and of the dispersion degree of the parameters studied, pointed out a different response, depending on fertilization and environmental conditions.

Of the two parameters of vegetation status analyzed, foliar area had a higher diversity index than chlorophyll content, but the range of variation in the experimental period, was lower. Chlorophyll content oscillated largely from one trial year to another, with lower values in 2012 compared with 2011 (Fig. 5). Results show the dependence of these parameters by the nutrition factors as independent variable within research and depending on environmental conditions. Chlorophyll content shows it is much more dependent on nutrition conditions than foliar area, which is more genetically determined. Mean yield per vine, and mean yield per ha also recorded a variation depending on both, trial variants and environmental conditions. Grape quality from the perspective of sugar content in must showed a wider variation depending on climate conditions than on fertilization level during the trial period (Fig. 6). Similar research concerning the influence of foliar fertilization on quantity and quality in different grapevine cultivars can be found in Rupp et al. (2002) and Lacroux et al. (2008). El Moniem and Abd-Allah (2008) studied the effect of the green algae cells extract, as foliar spray, on vegetative growth, yield and berries quality of superior grapevines and got favorable results in foliar area and grape yield correlated with algae extract concentration.

Comparative analysis of the dispersion of trial variants depending on vegetation parameters and dry matter content point out the influence of the climate conditions during the trial period. In 2011, there was a wider dispersion of the variants

\begin{tabular}{|c|c|c|c|c|c|c|c|}
\hline \multirow{2}{*}{\multicolumn{2}{|c|}{ Parameters }} & $\begin{array}{l}\text { Grape yield } \\
\text { per vine } \\
(\mathrm{kg})\end{array}$ & $\begin{array}{c}\text { Grape yield } \\
\text { per ha } \\
\left(\mathrm{t} \mathrm{ha}^{-1}\right)\end{array}$ & $\begin{array}{l}\text { Sugar } \\
(\mathrm{g} / \mathrm{l})\end{array}$ & $\begin{array}{l}\text { Grape yield } \\
\text { per vine } \\
(\mathrm{kg})\end{array}$ & $\begin{array}{c}\text { Grape yield } \\
\text { per ha } \\
\left(\mathrm{t} \mathrm{ha}^{-1}\right)\end{array}$ & $\begin{array}{l}\text { Sugar } \\
(\mathrm{g} / \mathrm{l})\end{array}$ \\
\hline & & \multicolumn{3}{|c|}{2011} & \multicolumn{3}{|c|}{2012} \\
\hline Control (Mt) & V1 & 1.94 & 8.46 & $190.00 \pm 1.20$ & 1.75 & 8.11 & $234.87 \pm 1.38$ \\
\hline Fertitel & $\mathrm{V} 2$ & $2.57^{* * *}$ & $9.80^{* *}$ & $193.02 \pm 1.42$ & $2.13^{*}$ & $9.19^{* * *}$ & $235.93 \pm 1.93$ \\
\hline Fertitel + Ca & V3 & $2.97^{* * *}$ & $12.50^{* * *}$ & $196.20 \pm 2.01$ & $2.35^{* *}$ & $10.42^{* * *}$ & $247.00 \pm 1.33$ \\
\hline Cropmax & V4 & 2.14 & $9.28^{*}$ & $194.33 \pm 0.58$ & 1.97 & $8.94^{* *}$ & $238.00 \pm 1.73$ \\
\hline Cropmax + Ca & V5 & $2.39^{* *}$ & $9.67^{* *}$ & $196.50 \pm 1.00$ & $2.19^{*}$ & $9.84^{* * *}$ & $253.07 \pm 3.46$ \\
\hline Waterfert & V6 & $2.27^{* *}$ & $9.48^{*}$ & $192.56 \pm 1.02$ & $2.16^{*}$ & $9.74^{* * *}$ & $241.03 \pm 1.49$ \\
\hline Waterfert + Ca & V7 & $2.66^{* * *}$ & $10.82^{* * *}$ & $195.56 \pm 1.74$ & $2.27^{* *}$ & $10.16^{* * *}$ & $258.89 \pm 4.14$ \\
\hline \multicolumn{2}{|c|}{$\begin{array}{l}\text { Limits the significance of } \\
\text { differences }\end{array}$} & $\begin{array}{l}\operatorname{LSD}_{5 \%}=0.229 \\
\operatorname{LSD}_{1 \%}=0.321 \\
\operatorname{LSD}_{0.01 \%}=0.454\end{array}$ & $\begin{array}{l}\operatorname{LSD}_{5 \%}=0.761 \\
\operatorname{LSD}_{1 \%}=1.069 \\
\operatorname{LSD}_{0.01 \%}=1.509\end{array}$ & & $\begin{array}{l}\mathrm{LSD}_{5 \%}=0.353 \\
\mathrm{SDL}_{1 \%}=0.495 \\
\mathrm{LSD}_{0,01 \%}=0.699\end{array}$ & $\begin{array}{l}\operatorname{LSD}_{5 \%}=0.605 \\
\operatorname{LSD}_{1 \%}=0.850 \\
\operatorname{LSD}_{0.01 \%}=1.200\end{array}$ & \\
\hline
\end{tabular}

Tab. 2. Yield and yield quality in the "Burgund" grapevine cultivar under the influence of foliar fertilization

Tab. 3. ANOVA test: Single Factor

\begin{tabular}{ccccccc}
\hline Source of Variation & SS & Df & MS & F & P-value & F crit \\
\hline Between Groups & 124318.7 & 7 & 17759.81 & 693.587 & $5.93 E-46$ & 4.257096 \\
\hline Within Groups & 1229.075 & 48 & 25.60574 & & & \\
\hline Total & 125547.7 & 55 & & & & \\
Alfa $=0.001$ & & & & &
\end{tabular}


depending on foliar area and a lower dispersion depending on chlorophyll content and dry matter, respectively. In 2012, a year with high rainfall deficit, variant dispersion amplitude depending on chlorophyll was narrower. It has retained a high dispersion of variants depending on leaf area, and has grown dispersion according to the dry matter content in the grapes.

Principal Component Analysis (PCA) facilitated variance assessment within groups and between groups of trial data, the orientation and grouping of the data depending on trial variants and parameters. There was high variance within groups in the variant $\mathrm{V}_{7}$ (Waterfert $+\mathrm{Ca}$ ) and narrower variance in the variant $\mathrm{V}_{2}$ (Fertitel); the other variants, including the control variant, had a moderate variation. Based on the PCA analysis, it was possible variants grouping into two distinct groups: a group $\mathrm{G}_{1}$ covering the variants $\mathrm{V}_{2}, \mathrm{~V}_{4}$ and $V_{6}$, and a second group, $G_{2}$, covering the variants $V_{3}$, $V_{5}$ and $V_{7}$. The main factor that generated variation between the two groups was the supplementary treatment with calcium associated to the group $\mathrm{G}_{2}$ (Fig. 7). The favorable effect of calcium on fruit



a



$\mathrm{b}$

Fig. 4. Particular distributions of the interdependence relationships between mean yield per ha and mean yield per vine in 2011 (a) and 2012 (b)

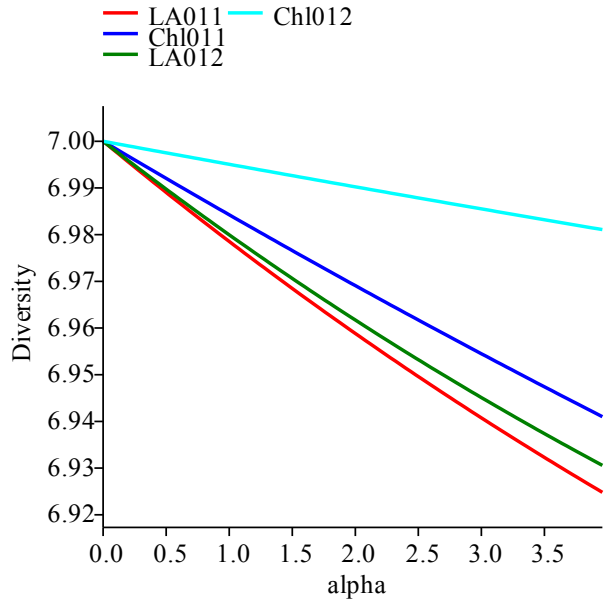
Note: LA011 - leaf area in 2011; LA012 - leaf area in 2012; Chl011 Y/vine011 - yield/vine 2011; Y/vine012 - yield/vine 2012; Y/ - chlorophyll content in 2011; Chl012 - chlorophyll content in ha011 - yield/ha-1 2011; Y/ha012 - yield/ha- 2012 ; S011 - sugar 2012.

Fig. 5. The amplitude of variation of vegetation parameter, expressed in terms of diversity index

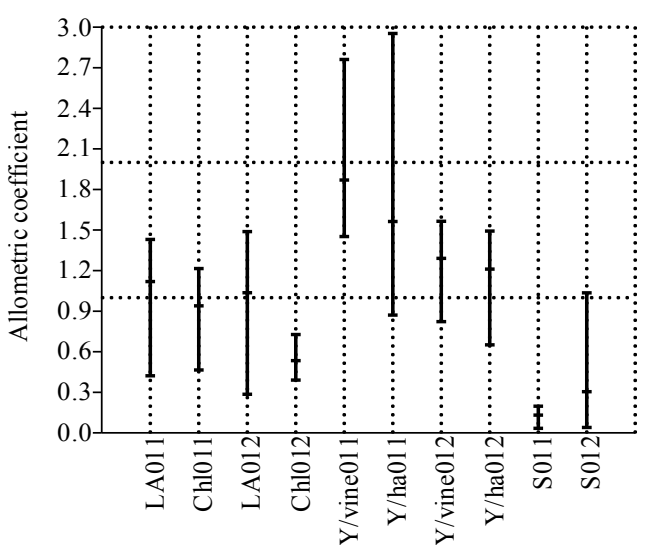

Note: LA011 - leaf area in 2011; LA012 - leaf area in 2012; Chl011 chlorophyll content in 2011; Chl012 - chlorophyll content in 2012; content 2011; S012 - sugar content 2012.

Fig. 6. Multivariate allometry, 95\% confidence for vegetation parameter and yield 


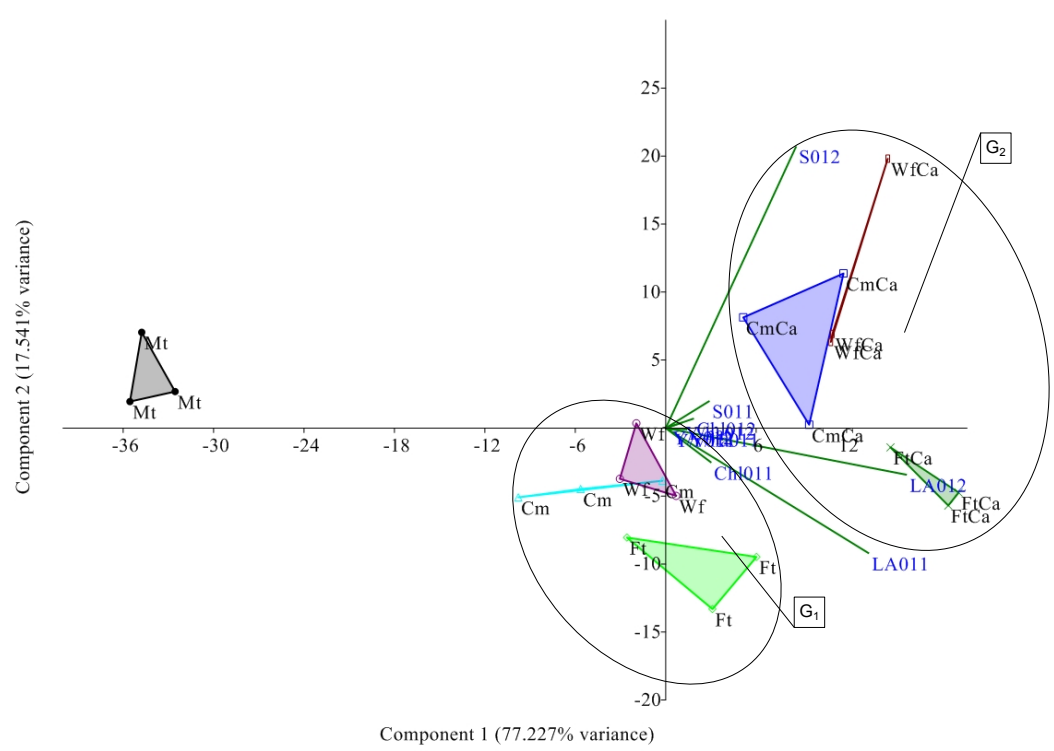

Note: Mt - control variant $\left(\mathrm{V}_{1}\right)$; Ft - Fertitel $\left(\mathrm{V}_{2}\right)$; FtCa - Fertitel + CalcioPlus $\left(\mathrm{V}_{3}\right) ; \mathrm{Cm}-\operatorname{Cropmax}\left(\mathrm{V}_{4}\right)$; CmCa - Cropmax + CalcioPlus $\left(\mathrm{V}_{5}\right)$; Wf Waterfert $\left(\mathrm{V}_{6}\right)$; WaCa - Waterfert + CalcioPlus $\left(\mathrm{V}_{7}\right)$.

Fig. 7. Variance between groups: orientation and grouping of trial variants depending on the parameters measured; group $G_{1}$ - variants without supplementary lime supply; group $G_{2}$ - variants with supplementary lime supply.

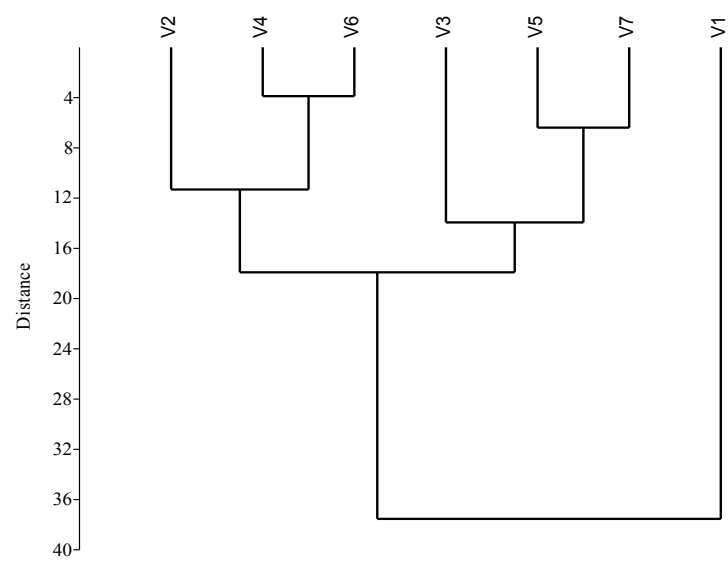

Note: $\left(\mathrm{V}_{1}\right)$ - control variant; $\left(\mathrm{V}_{2}\right)$ Fertitel; $\left(\mathrm{V}_{3}\right)$ Fertitel + CalcioPlus; $\left(\mathrm{V}_{4}\right)$ Cropmax; $\left(\mathrm{V}_{5}\right)$ Cropmax + CalcioPlus; $\left(\mathrm{V}_{6}\right)$ Waterfert; $\left(\mathrm{V}_{7}\right)$ Waterfert + CalcioPlus.

Fig. 8. Grouping trial variants within the Euclidean distance based on similarity

quality was also studied in kiwi (Basiouny and Basiouny, 2000; Koutinas et al., 2010), grapes (Raath, 2012), blueberry (Ochmian, 2012), apple (Jivan and Sala, 2014).

Multi-parameter analysis of trial data facilitated the grouping of the variants based on affinity (Euclidean distances) in the generation of the analyzed parameter values. The control variant holds a separate position because of the low values of the parameters generated. The variants fertilized are summarized within a large cluster with two sub-clusters depending on affinities: $V_{2}, V_{4}$ and $V_{6}$ within a sub-cluster, and $V_{3}, V_{5}, V_{7}$ within the other sub-cluster (Fig. 8). Cophenetic coefficient value was 0.940 , which makes the group obtained based on trial variant similarity highly ensured statistically.

\section{Conclusion}

Monitoring nutrition through foliar fertilization in grapevine ("Burgund" cultivar) caused a differentiated variation of the morphophysiological and productivity parameters depending on fertilization variants. At the same time, there was also a variation depending on vegetation conditions (particularly climate ones) during the trial period.

Leaf area and chlorophyll content as parameters of the vegetation state expressed grapevine nutrition differently depending on both fertilization and climate conditions (variations). Sugar content as indicator of grape quality differed because of foliar fertilization. The supplementary supply of calcium caused, within the same variants, a significant increase of sugar content. 
Calcium supply plays a significant role in both quantity and quality, causing the obvious separation of the trial variants into two distinct groups through PCA analysis and multivariate analysis based on Euclidean distances

Acknowledgements. The authors express thanks to the leaders and staff of the didactic and experimental station of the Banat University of Agricultural Sciences and Veterinary Medicine „Regele Mihai I al României” of Timișoara, Romania, Fruit-Vine Research Center, for facilitating the setup of the experimental field for this research.

\section{References}

1. Andrés-de-Prado R, Yuste-Rojas $M$, Sort $X$, AndrésLacueva C, Torres M, Lamuela-Raventós RM (2007). Effect of soil type on wines produced from Vitis vinifera $\mathrm{L}$. cv. Grenache in commercial vine yards. J Agric Food Chem 55(3):779-786.

2. Barbeau G, Cadot Y, Stevez L, Bouvet MH, Cosneau M, Asselin C, Mege A (2001). Role of soil physical properties, climate and harvest period on must composition, wine type and flavour (Vitis vinifera L., cv. Chenin). Proceedings of the $26^{\text {th }}$ world congress of the OIV Adelaide, Australia, 11-17 Oct:1-12.

3. Basiouny FM, Basiouny A (2000). Effects of liquid calcium and controlled atmosphere on storability and quality of kiwifruit (Actinidia chinensis Planch cv. 'Hayward'). Acta Hort 518:213-221.

4. Bassoi LH, Hopmans JW, de Castro Jorge LA, de Alencar CM, Moura e Silva JA (2003). Grapevine root distribution in drip and microsprinkler irrigation. Sci Agric 60(2):377387.

5. Bauerle TL, Smart DR, Bauerle WL, Stockert C, Eissenstat DM (2008). Root foraging in response to heterogeneous soil moisture in two grapevines that differ in potential growth rate. New Phytol 179(3):857-866.

6. Blidariu C, Boldea M, Sala F (2013). Aspects of modeling regarding the contribution of nitrogen to the formation of grape yields. AIP Conf Proc 1558:1575-1578.

7. Brataševec K, Sivilotti P, Vodopivec BM (2013). Soil and foliar fertilization affects mineral contents in Vitis vinifera L. cv. 'rebula' leaves. J Soil Sci Plant Nutr 13(3):650-663.

8. Charters S (2010). Marketing terroir: A conceptual approach. Refereed paper $-5^{\text {th }}$ Int Acad Wine Business Res Conf 8-10 Feb. 2010 Auckland (NZ):1-8.

9. Colapietra M, Alexander A (2006). Effect of foliar fertilization on yield and quality of table grapes. Proc. $5^{\text {th }}$ IS on Mineral Nutrition of Fruit Plants, Eds. J. B. Retamales and G. A. Lobos, Acta Hort. 721.

10. Cross R, Plantinga AJ, Stavins RN (2011). What Is the Value of Terroir? American Economic Review: Papers \& Proceedings 101(3):152-156.

11. El Moniem EAA, Abd-Allah ASE (2008). Effect of green alga cells extract as foliar spray on vegetative growth, yield and berries quality of superior grapevines. AmericanEurasian J Agric Environ Sci 4(4):427-433.

12. Felder D, Burns D, Chang D (2012). Defining microbial terroir: The use of native fungi for the study of traditional fermentative processes. International Journal of Gastronomy and Food Science 1(1):64-69.

13. Freitas NO, Yano-Melo AM, Barbosa da Silva FS, de Melo NF, Maia LC (2011). Soil biochemistry and microbial activity in vineyards under conventional and organic management at Northeast Brazil. Scientia Agricola 68(2):223-229.

14. Gerasopoulos D, Chouliaras V, Lionakis S (1996). Effects of preharvest calcium chloride sprays on maturity and storability of Hayward kiwifruit. Postharvest Biol Tec 7(12):65-72.

15. Gluhić D, Ćustić MH, Petek M, Čoga L, Slunjski S, Sinčić $\mathrm{M}$ (2009). The Content of $\mathrm{Mg}, \mathrm{K}$ and $\mathrm{Ca}$ ions in vine leaf under foliar application of magnesium on calcareous soils. Agric Conspec Sci 74(2):81-84.

16. Hammer $\varnothing$, Harper DAT, Ryan PD (2001). PAST: Paleontological statistics software package for education and data analysis. Palaeontol Electron 4(1):1-9.

17. Jackson DI, Lombard PB (1993). Environmental and management practices affecting grape composition and wine quality - A Review. Am J Enol Vitic 44(4):409-430.

18. Jivan C, Sala F (2014). Relationship between tree nutritional status and apple quality. Hort. Sci. (Prague) 41(1):1-9.

19. Koutinas N, Sotiropoulos T, Petridis A, Almaliotis D, Deligeorgis E, Therios I, Voulgarakis N (2010). Effects of preharvest calcium foliar sprays on several fruit quality attributes and nutritional status of the kiwifruit cultivar Tsechelidis. HortScience 45(6):984-987.

20. Lacroux F, Tregoat O, Van Leeuwen C, Pons A, Tominaga T, Lavigne-Cruège V, Dubourdieu D (2008). Effect of foliar nitrogen and sulphur application on aromatic expression of Vitis vinifera L. cv. Sauvignon Blanc. J Int Sci Vigne Vin 42(3):1-8.

21. Lambert JJ, Dahlgren RA, Battany M, McElrone A, Wolpert JA (2008). Impact of soil properties on nutrient availability and fruit and wine characteristics in a Paso Robles vineyard. $2^{\text {nd }}$ Ann Nat Vitic Res Conf Proc, University of California, 44-45.

22. Mackenzie DE, Christy AG (2005). The role of soil chemistry in wine grape quality and sustainable soil management in vineyards. Water Sci Technol 51(1):27-37.

23. Mouton DG (2006). Terroir - the footprint of great wines. PhD Thesis, Cape Wine Academy.

24. Neilsen GH, Stevenson DS, Fitzpatrick JJ (1989). The effect of municipal wastewater irrigation and rate of $n$ fertilization on petiole composition, yield and quality of Okanagan Riesling grapes. Can J Plant Sci 69:1285-1294.

25. Ochmian ID (2012). The impact of foliar application of calcium fertilizers on the quality of high bush blueberry fruits belonging to the 'Duke' cultivar. Not Bot Horti Agrobo 40(2):163-169.

26. Oliver DP, Bramley RGV, Riches D, Porter I, Edwards J (2013). Review: soil physical and chemical properties as 
indicators of soil quality in Australian viticulture. Aust Grape Wine Res 19(2):129-139.

27. Raath PJ (2012). Effect of varying levels of nitrogen, potassium and calcium nutrition on table grape vine physiology and berry quality. PhD Thesys, Supervisor Prof J. J. Hunter, Co-Supervizor Dr. W. J. Conradie, Stellenbosch University, Department of Viticulture and Oenology, Faculty of AgriSciences.

28. Rotaru L, Filipov F, Mustea M, Stoleru V (2010). Influence of some "Terroir Viticole" factors on quantity and quality of grapes. Not Bot Hort Agrobot 38(1):176-181.

29. Rupp D, Fox R, Tränkle L (2002). Foliar application of magnesium fertilizer in grapevines: effects on wine quality. Acta Hort (ISHS) 594:149-155.

30. Sala F, Blidariu C (2012). Macro- and micronutrient content in grapevine cordons under the influence of organic and mineral fertilization. Bulletin UASVM Horticulture 69(1):317-324.

31. Sala F, Blidariu C, Dobrei A, Boldea M (2013). The variation of some vegetation and quality indices in grapes under the influence of foliar fertilization on grapevine. Bulletin UASVM Horticulture 70(1):201-208.

32. Smith R, Bettiga L, Cahn MD, Baumgartner K, Jackson LE, Bensen $T$ (2008). Vineyard floor management affects soil, plant nutrition, and grape yield and quality. Calif Agr 62(4):184-190.
33. Šimanský V, Ložek O (2013). Fertilization of vine by a 5-aminolevulinic acid-based fertilizer and its profitability. Journal of Central European Agriculture 14(1):270-283.

34. Spayd SE, Wample RL, Evans RG, Stevens RG, Seymour BJ, Nagel CW (1994). Nitrogen fertilization of white riesling grapes in Washington. Must and wine composition. Am J Enol Vitic 45(1):34-42.

35. Teil G (2012). No such thing as terroir? Objectivities and the regimes of existence of objects. Sci Technol Human Values 37(5):478-505.

36. Van Leeuwen C, Friant $P$, Choné $X$, Tregoat $O$, Koundouras S, Dubourdieu D (2004). Influence of climate, soil, and cultivar on terroir. Am J Enol Vitic 55(3):207-217.

37. Van Leeuwen C, Seguin G (2006). The concept of terroir in viticulture. Journal of Wine Research, 17(1):1-10.

38. Wade J, Holzapfel B, Degaris K, Williams D, Keller M (2004). Nitrogen and water management strategies for wine-grape quality. Acta Hort 640:61-67.

39. Wiens G, Reynolds AG (2008). Efficacy testing of organic nutritional products for Ontario Canada vineyards. Int J Fruit Sci 8(1-2):125-145.

40. ${ }^{* * *}$ IFA World Fertilizer Use Manual (1992). www. spectrumanalytic.com, Fertilizing Grapes. 